\title{
PENGARUH PENERAPAN COOPERATIVE LEARNING TIPE STAD TERHADAP HASIL BELAJAR SISWA KELAS X TEKNIK AUDIO VIDEO DI SMK NEGERI I SUMBAR
}

\author{
Witri Ramadhani ${ }^{1}$, Fauzan Azim ${ }^{2}$, Hadi Purwanto ${ }^{3}$ \\ ${ }^{1,2,3}$ Program Studi Pendidikan Teknik Elektronika, Program Studi IPA \\ FKIP Universitas Muhammadiyah Riau \\ e-mail: ${ }^{1}$ witrirahmadhani@umri.ac.id, ${ }^{2}$ fauzanazim@umri.ac.id, ${ }^{3}$ hadipurwanto@umri.ac.id
}

\begin{abstract}
Abstrak
Model pembelajaran kooperatif tipe STAD adalah model pembelajaran yang memotivasi siswa untuk bekerjasama dalam kelompok proses belajar mengajar. Penelitian ini menggunakan pendekatan kuantitatif dengan metode eksperimen. Populasi penelitian ini adalah siswa kelas X TAV SMK Negeri 1 Sumbar Tahun Ajaran 2013/2014. Teknik pengambilan sampel adalah purposive. Tes terdiri dari 27 item yang telah diuji validitas dan reliabilitasnya, pengujian hipotesis menggunakan t-test Polled Variance. Dari hasil penelitian, skor rata-rata hasil belajar siswa menggunakan model Cooperative Learning tipe STAD adalah 81,17 sedangkan skor rata-rata hasil belajar siswa menggunakan metode pembelajaran langsung adalah 74,85. Secara keseluruhan kelas eksperimen signifikan daripada kelas kontrol dengan persentase pengaruh $8,44 \%$ sehingga ada pengaruh penerapan model pembelajaran Kooperatif tipe STAD pada siswa kelas X teknik audio-video di SMK Negeri 1 Sumbar.
\end{abstract}

Kata kunci: Pembelajaran kooperatif tipe STAD, Model Pembelajaran, Pembelajaran Langsung, Kontrol dan Eksperimen

\begin{abstract}
Cooperative Learning model type STAD is a learning model that motivates students to work together within the teaching and learning process groups. This study used a quantitative approach to the experimental method. The population of this study was students of class X TAV of SMK Negeri 1 Sumbar Academic Year 2013/2014. The sampling technique was purposive. The test consisted of 27 items that had been tested for validity and reliability, hypothesis testing used $t$-test Polled Variance. From the research result, the average score of the learning result of students using the Cooperative Learning model type STAD is 81,17 while the average score of the learning result of students using the direct learning method is 74,85. Overall experiment class significantly than control class with influence percentage 8,44\% there was so influence of the implementation of Cooperative Learning model type STAD in students class $X$ audio-video technique in SMK Negeri 1 Sumbar.
\end{abstract}

Keywords: Cooperative Learning type STAD, Learning Model, Direct Learning, Control and Experiment 


\section{Pendahuluan}

Pendidikan merupakan faktor penting dalam kehidupan seseorang karena melalui pendidikan dapat meningkatkan kecerdasan potensi diri dan dapat membentuk pribadi yang bertanggung jawab serta kreatif yang berguna untuk dirinya, masyarakat, bangsa dan negara. Belajar merupakan proses untuk mencapai faktor penting tersebut dimana mengandung perubahan tingkah laku pada diri individu dengan lingkungan dan peningkatan mutu pendidikan. Peningkatan mutu pendidikan sangat diperlukan karena menghasilkan sumber daya manusia yang cerdas dan berkualitas sesuai tuntutan perkembangan zaman, salah satu jenjang pendidikan untuk mencapai keberhasilan dibidang pendidikan adalah sekolah menengah kejuruan (SMK).

Sekolah Menengah Kejuruan (SMK) berfungsi untuk meningkatkan sumber daya manusia dan bertujuan untuk menyiapkan tenaga tingkat menengah memiliki pengetahuan, keterampilan serta sikap sesuai dengan spesialisasi kejuruan yang diantaranya adalah SMK Negeri 1 Sumbar. Salah satu mata pelajaran yang ada di jurusan teknik audio video SMK N 1 Sumbar yang dapat meningkatkan keterampilan serta sikap peserta didik adalah mata diklat Memahami Sifat Dasar Sinyal Audio (MSDSA). Mata diklat ini merupakan mata pelajaran yang menjadi dasar bagi bidang keahlian Teknik Audio Video, didalam MSDSA tercakup materi menjelaskan decibel dan menjelaskan konversi besaran listrik pada mikrophon dan loudspeaker semua materi tersebut dibagi menjadi beberapa kompetensi yang akan diajarkan oleh guru.

Setiap siswa kelas X Teknik Audio Video wajib mengikuti mata diklat MSDSA dan harus lulus untuk setiap kompetensi yang dapat dibuktikan dengan hasil belajar memenuhi kriteria ketuntasan minimal (KKM). Menurut Soedijarto dalam Sadirman (2012:38) "Hasil belajar dapat berupa pengetahuan yang diperoleh setelah siswa menempuh aktivitas". Melihat berhasil atau tidaknya hasil proses belajar siswa, maka perlu adanya standar kriteria ketuntasan atau keberhasilan belajar yang disebut dengan kriteria ketuntasan minimal (KKM).

Menurut Surat Dirjendikdasmen No 132/c4/MN/2004 tentang Pengkajian Standar Ketuntasan Minimal, berdasarkan petunjuk dari Badan Standar Nasional Pendidikan (BNSP) tahun 2006 "Setiap sekolah dapat menentukan standar ketuntasan sekolahnya sendiri'. Terlihat pada SMK N 1 Sumbar pada mata pelajaran Memahami Sifat Dasar Sinyal Audio memiliki batas KKM adalah 80, siswa yang nilainya dibawah KKM maka guru akan selalu mengadakan remedial agar seluruh siswa dapat mencapai KKM yang telah ditetapkan sekolah.

Hasil observasi yang dilakukan di SMK Negeri 1 Sumbar terhadap proses pembelajaran di jurusan teknik audio video didapatkan bahwa proses pembelajaran terpusat pada guru terlihat dari kemampuan siswa dalam mengerjakan tugas-tugas yang diberikan guru kepada siswa belum dapat dijawab sesuai dengan kriteria yang diharapkan, serta model yang digunakan guru belum bervariasi sesuai harapan dan kemampuan siswa.

Memperhatikan kondisi tersebut perlu dilakukan suatu pendekatan belajar yang memberikan nuansa baru dalam belajar serta memperbaiki hasil belajar siswa menjadi lebih baik sesuai dengan kriteria ketuntasan minimal (KKM). Pendekatan belajar yang dapat diterapkan memperbaiki masalah diatas yaitu dengan pengembangan model pembelajaran. Model pembelajaran yang dapat diterapkan yaitu menerapkan model pembelajaran kooperatif. Menurut Slavin (2005:8) "Pembelajaran kooperatif adalah para siswa akan duduk bersama dalam kelompok yang beranggotakan empat orang untuk menguasai materi yang disampaikan oleh guru". Pembelajaran kooperatif dirancang untuk memberi dorongan kepada peserta didik agar bekerja sama selama proses pembelajaran, serta berdampak positif untuk siswa yang rendah hasil belajar.

Cooperative Learning memiliki banyak tipe pembelajaran yang dapat diterapkan salah satunya adalah tipe STAD yang dapat diterapkan dalam masalah di atas. Melalui Cooperatif Learning tipe STAD pembelajaran menjadi lebih baik, melibatkan siswa dalam kelompok dan belajar untuk satu sama lain serta dapat membantu siswa dalam memperbaiki hasil belajar menjadi lebih baik lagi sesuai dengan KKM sekolah. 


\section{Metode Penelitian}

Penelitian ini menggunakan pendekatan kuantitatif dengan metode eksperimen yang bertujuan untuk menilai pengaruh suatu perlakuan pendidikan terhadap tingkah laku peserta didik. Menurut A.Muri Yusuf (2005:229) Rancangan penelitian ini dapat dilihat dapat dilihat pada tabel dibawah ini.

Tabel 1. Rancangan penelitian The Static Group Comparison Design.

\begin{tabular}{lcc}
\hline \multicolumn{1}{c}{ Kelas } & Treatment & Post Test \\
\hline Eksperimen & $\mathrm{X}$ & $\mathrm{O} 1$ \\
\hline Kontrol & - & $\mathrm{O} 2$
\end{tabular}

Keterangan :

$\mathrm{X}$ : Perlakuan yang diberikan pada kelas eksperimen, yaitu model pembelajaran kooperatif tipe STAD.

- : Perlakuan yang diberikan pada kelas kontrol yaitu model pembelajaran langsung.

O1: Tes akhir yang diberikan pada kelas eksperimen.

O2: Tes akhir yang diberikan pada kelas kontrol.

Menurut Sugiyono (2013:6) Variabel penelitian adalah "Suatu atribut atau sifat atau nilai dari orang, objek atau kegiatan yang mempunyai variasi tertentu yang ditetapkan oleh peneliti untuk dipelajari dan kemudian ditarik kesimpulannnya. Variabel bebas (X) dalam penelitian ini adalah model pembelajaran kooperatif tipe STAD (X).Variabel terikat (Y) dalam penelitian ini adalah hasil belajar memahami sifar dasar sinyal audio yang diperoleh setelah pelaksanaan pembelajaran kooperatif tipe STAD (Y).

Penelitian ini dirancang untuk mendeskripsikan seberapa besar pengaruh penerapan model pembelajaran kooperatif tipe STAD sebagai variabel bebas (X) terhadap hasil belajar siswa pada mata pelajaran memahami sifat dasar sinyal audio sebagai variabel terikat (Y) kelas X teknik audio video SMK Negeri 1 Sumbar. Menurut Sugiyono (2013:117) populasi adalah "Wilayah yang terdiri atas objek yang mempunyai kualitas dan karakteristik tertentu yang ditetapkan oleh peneliti untuk dipelajari dan kemudian ditarik kesimpulannya".

Populasi dalam penelitian ini adalah semua siswa kelas X Teknik Audio Video di SMK Negeri 1 Sumbar yang terdaftar pada Semester Genap tahun 2013/2014. Menurut Sugiyono (2013:118) sampel adalah "Bagian dari jumlah dan karakteristik yang dimiliki oleh populasi". Sampel penelitian adalah sebagian dari populasi yang diambil sebagai sumber data dan mewakili seluruh populasi. Sampel yang diambil berkategori probality sampling (setiap individu yang terdapat dalam populasi dapat dijadikan sampel).

Jumlah sampel ditetapkan 25 orang siswa dengan menggunakan dua kelas sampel yang terdiri dari satu kelas eksperimen dan satu kelas kontrol, sampel dalam penelitian menggunakan teknik sampling purposive. Setelah dilakukan teknik sampling purposive ditetapkan sebagai kelas eksperimen adalah kelas XTAV2 yang berjumlah 12 orang dan sebagai kelas kontrol adalah kelas XTAV1 yang berjumlah 13 orang dengan rincian pada Tabel 2.

Tabel 2. Distribusi penyebaran sampel siswa kelas X TAV SMK N 1 Sumbar Semester Genap Tahun Ajaran 2013/2014.

\begin{tabular}{lcc}
\hline \multicolumn{1}{c}{ Kelas } & Kelas & Jumlah Siswa \\
\hline Kontrol & X TAV 1 & 13 \\
\hline Eksperimen & X TAV 2 & 12 \\
\hline
\end{tabular}


Pelaksanaan penelitian ini siswa dibedakan menjadi dua kelas yaitu kelas eksperimen dan kelas kontrol. Kedua kelas ini mendapatkan perlakuan yang berbeda, kelas eksperimen merupakan kelompok siswa yang diberikan perlakuan model pembelajaran kooperatif tipe STAD sedangkan kelas kontrol tidak diberikan perlakuan, pada akhir pembelajaran kedua kelas ini akan sama-sama diberikan tes akhir.

Menurut Suharsismi (2010:60) prosedur penelitian dibagi tiga bagian:

\subsection{Tahap persiapan}

a. Menetapkan jadwal penelitian

b. Mengurus izin penelitian

c. Mempersiapkan perangkat pembelajaran silabus, rencana pelaksanaan pembelajaran (RPP)

d. Mempersiapkan kisi-kisi soal

e. Membentuk kelompok siswa, menurut Slavin (2005:152) "Membagi siswa kedalam tim". Sesuai dengan Tabel 3 .

Tabel 3. Membagi Siswa ke dalam Tim

\begin{tabular}{ccc}
\hline Prestasi Siswa & Peringkat & Nama Tim \\
\hline \multirow{3}{*}{ Siswa berprestasi tinggi } & 1 & $\mathrm{~A}$ \\
\cline { 2 - 3 } & 2 & $\mathrm{~B}$ \\
\cline { 2 - 3 } & 3 & $\mathrm{C}$ \\
\cline { 2 - 3 } Siswa berprestasi sedang & 4 & $\mathrm{C}$ \\
\cline { 2 - 3 } & 5 & $\mathrm{~B}$ \\
\cline { 2 - 3 } & 7 & $\mathrm{~A}$ \\
\cline { 2 - 3 } & 8 & $\mathrm{~A}$ \\
\cline { 2 - 3 } Siswa berprestasi rendah & 9 & $\mathrm{~B}$ \\
\cline { 2 - 3 } & 10 & $\mathrm{C}$ \\
\hline & 11 & $\mathrm{~B}$ \\
\hline
\end{tabular}

f. Mempersiapkan tes untuk penilaian hasil belajar yang akan digunakan setelah diberikan perlakukan kelas sampel

\subsection{Tahap pelaksanaan}

Pada kelas eksperimen dilakukan pembelajaran yang merupakan tipe STAD sedangkan pada kelas kontrol pembelajaran dilaksanakan tanpa menggunakan tipe STAD.

\subsection{Tahap Penyelesaian}

Tahap akhir kelas sampel diberikan tes akhir berupa tes objektifsetelah pokok bahasan selesai, pada tahap ini dilakukan peneliti adalah :

a. Mengadakan tes hasil belajar pada kedua kelas sampel setelah perlakuan penelitian pembelajaran berakhir.

b. Mengolah data dari kedua sampel, baik di kelas eksperimen maupun kelas kontrol. 
c. Menarik kesimpulan dari hasil yang didapat sesuai dengan teknis analisis data yang digunakan

Jenis instrumen digunakan adalah tes hasil belajar yang diuji validitas dan reliabilitasnya, analisis bertujuan mengembangkan keadaan data apa adanya yang dikumpulkan dari sampel, disajikan dalam tabel distribusi frekuensi, kemudian dihitung mean, varians dan standar deviasi. Prasyarat uji hipotesis dilakukan beberapa pengujian: (1)Uji normalitas menggunakan uji lilifors, (2) Uji Homogenitas Variasi menggunakan uji F (3) Uji hipotesis menggunakan teknik Uji t-test Polled Varians dan (4) Persentase pengaruh.

\section{Hasil dan Pembahasan}

Penelitian ini mengungkapkan bahwa dari 25 siswa yang dijadikan sampel dalam penelitian ini dengan menjawab 27 butir item dalam rangka melihat pengaruh penerapan cooperative learning tipe STAD terhadap hasil belajar siswa.

\subsection{Analisis Deskriptif}

Analisis deskriptif untuk kelas eksperimen dan kelas kontrol terlihat pada table 2.

Tabel 2. Analisis deskriptif untuk kelas eksperimen

\begin{tabular}{clc}
\hline No & Statistik & Hasil Belajar \\
\hline 1 & $\mathrm{~N}$ & 12 \\
\hline 2 & Mean & 81,17 \\
\hline 3 & Varians & 52,54 \\
\hline 4 & Std.Deviasi & 7,25 \\
\hline 5 & Skor tertinggi & 93 \\
\hline 6 & Skor terendah & 67 \\
\hline 7 & Range & 26 \\
\hline
\end{tabular}

Analisis deskriptif kelas eksperimen jumlah sampel $(\mathrm{N})$ adalah 12 dengan nilai rata-rata (Mean) lebih tinggi dari nilai kelas kontrol yaitu sebesar 81,17. Varians adalah 52,54. Standar deviasi atau simpangan baku adalah 7,25 sedang skor tertinggi adalah 93 dan skor terendah adalah 67 sehingga diperoleh range dari keduanya sebesar 26 yang terlihat pada kurva dibawah dengan keaadaan normal.

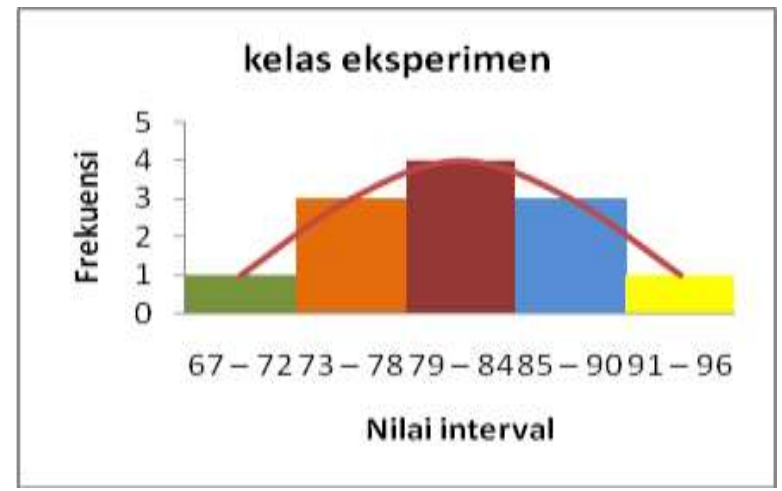

Gambar 1. Kurva kelas eksperimen 
Tabel 3. Analisis deskriptif untuk kelas kontrol

\begin{tabular}{clc}
\hline No & Statistik & Hasil Belajar \\
\hline 1 & $\mathrm{~N}$ & 13 \\
\hline 2 & Mean & 74,85 \\
\hline 3 & Varians & 40,50 \\
\hline 4 & Std.Deviasi & 6,36 \\
\hline 5 & Skor tertinggi & 85 \\
\hline 6 & Skor terendah & 63 \\
\hline 7 & Range & 22 \\
\hline
\end{tabular}

Analisis deskriptif kelas kontrol jumlah sampel $(\mathrm{N})$ adalah 13 dengan nilai rata-rata (Mean) lebih rendah dari nilai kelas eksperimen yaitu sebesar 74,85. Varians adalah 40,50. Standar deviasi atau simpangan baku adalah 6,36 sedang skor tertinggi adalah 85 dan skor terendah adalah 63 sehingga diperoleh range dari keduanya sebesar 22 yang terlihat pada kurva di bawah dengan keaadaan normal.

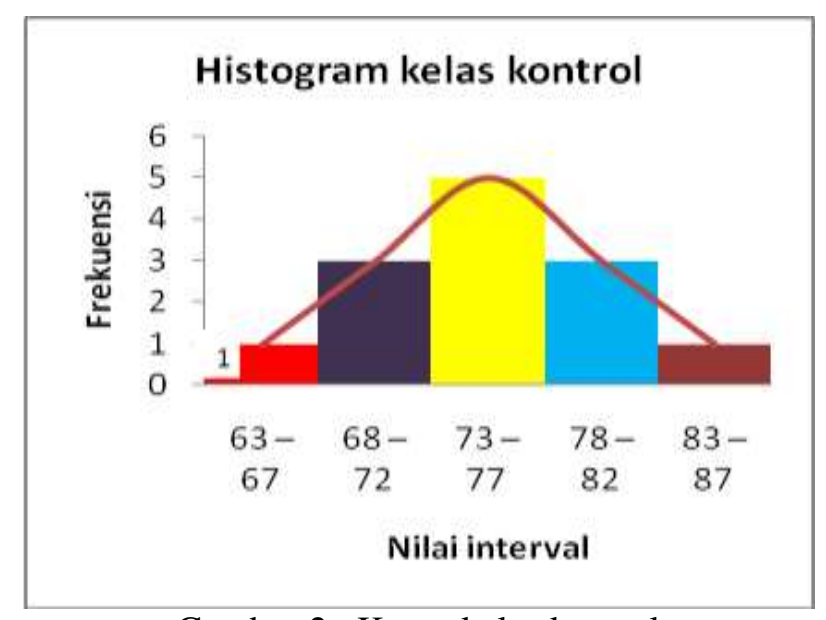

Gambar 2. Kurva kelas kontrol

\subsection{Analisis Induktif}

1. Hasil Uji Normalitas

Menurut Nana Sudjana (2009:120) Uji nomalitas data di gunakan untuk mengetahui apakah penyebaran data berdistribusi normal atau tidak, dalam penelitian ini uji normalitas data menggunakan uji liliefors karena masing- masing sampel kurang dari 33 sampel. Perhitungan liliefors kelas eksperimen dengan membandingkan Lo yang di peroleh dari harga yang paling besar dari selisih $\mathrm{F}(\mathrm{Zi})$ - $\mathrm{S}(\mathrm{Zi})$ dengan nilai Lt untuk $\alpha=0,05$ dan $\mathrm{n}=12$, pada tabel nilai kritis $\mathrm{L}$ di dapat $\mathrm{Lt}=0,242 \mathrm{dan} \mathrm{Lo}=0,141$. Jika Lo $<\mathrm{Lt}$, artinya distribusi normal dan sebaliknya, hasil yang didapat $\mathrm{Lo}<\mathrm{Lt}$ atau $(0,141<0,242)$, maka data terdistribusi normal.

Perhitungan liliefors kelas kontrol dengan membandingkan Lo yang di peroleh dari harga yang paling besar dari selisih $\mathrm{F}(\mathrm{Zi})-\mathrm{S}(\mathrm{Zi})$ dengan nilai Ltuntuk $\alpha=0,05$ dan $\mathrm{n}=13$, maka dicari pada tabel nilai kritis $\mathrm{L}$ di dapat $\mathrm{Lt}=0,234$ dan $\mathrm{Lo}=0,090$ dengan hasil $\mathrm{Lo}<\mathrm{Lt}$ atau $(0,090<0,234)$ maka data terdistribusi normal. 


\section{Hasil Uji Homogenitas}

Uji homogenitas bertujuan untuk mengetahui apakah kedua kelompok data mempunyai varian yang homogen atau membandingkan Fhitung dengan Ftabel. Hasil analisis data telah diperoleh bahwa Fhitung $<$ Ftabel atau $1,14<2,79$ berarti kedua kelompok sampel mempunyai varian yang homogen.

\section{Uji Hipotesis}

Uji Hipotesis dalam penelitian ini menggunakan rumus t-test Polled Varians karena data berdistribusi normal dan kedua kelompok data homogen $\left(\sigma^{2} 1=\sigma^{2} 2\right)$, namun jumlah sampel pada kelas sampel berbeda $(n 1 \neq n 2)$ dan besar derajat kebebasan $(d k=n 1+n 2-2)$. Kriteria pengujian : Hipotesis Ho diterima jika $t$ hitung $<\mathrm{t}$ tabel. Ho ditolak jika thitung $>\mathrm{ttabel}$, ttabel didapat dari tabel distribusi $t$ dengan derajat kebebasan $\mathrm{dk}=\mathrm{n} 1+\mathrm{n} 2-2$ dan peluang $(1-\alpha)$ dengan $\alpha=0,005$.

Perolehan dari hasil penelitian di dapat thitung>ttabel yaitu 3,16> 1,713872),bearti Ho ditolak dan $\mathrm{H} 1$ diterima. Hasil pengujian ini memberikan interprestasi bahwa terdapat pengaruh yang positif dan signifikan pada pembelajaran memahami sifat dasar sinyala udio di SMK Negeri 1 Sumbar, hasil penelitian diperoleh nilai t hitung $=3,16$ yang jatuh pada daerah kritis dengan $\alpha=0$, 05. Jadi Ho ditolak hal ini bearti penerapan model pembelajaran koperatife tipe STAD memberikan pengaruh terhadap hasil belajar siswa pada mata pelajaran memahami sifat dasar sinyal audio di kelas X Teknik audio video SMK Negeri 1 Sumbar.

\section{Persentase Pengaruh}

Persentase pengaruh digunakan untuk menjelaskan seberapa besar pengaruh kooperatif tipe STAD terhadap hasil belajar siswa pada mata pelajaran memahami sifat dasar sinyal audio kelas X Teknik Audio Video SMK Negeri 1 Sumbar. Hasil test akhir yang telah peneliti lakukan pada di pada kelas eksperimen rata-rata hasil belajar siswa adalah 81,17 sedangkan pada kelas kontrol rata-rata hasil belajar siswa adalah 72,85.

Rata-rata hasil belajar ini dimasukan ke dalam rumus di atas diperoleh persentase pengaruh pembelajaran kooperatife tipe STAD terhadap hasil belajar siswa pada mata pelajaran memahami sifat dasar sinyal audio kelas X Teknik Audio Video SMK Negeri 1 Sumbar adalah $8,44 \%$.

\subsection{Pembahasan}

Setelah dilakukan proses pembelajaran pada kelas eksperimen yang menerapkan model pembelajaran Cooperatife tipe STAD dan kelas kontrol yang menerapkan model pembelajaran langsung terlihat hasil belajar kedua kelas berbeda secara nyata. Rata-rata hasil belajar kelas eksperimen sebesar 81,17 sedangkan rata-rata hasil belajar kelas control sebesar 74,85. Dibuktikan dari hasil uji t sebesar t-hitung $(3,16)>$ t-tabel $(1,713872)$ yang bearti H1 diterima dan Ho ditolak. Secara keseluruhan diperoleh bahwa pada kelas eksperimen jauh lebih baik dibandingkan dari pada kelas control dengan persentase pengaruh 8,44\%. Keadaan ini didorong oleh sistem yang ada dalam model pembelajaran kooperatife tipe STAD itu sendiri.

\section{Kesimpulan}

Berdasarkan penelitian dan analisa terhadap hipotesis penelitian pengaruh penerapan cooperative learning tipe STAD terhadap hasil belajar siswa kelas X di SMK Negeri 1 Sumbar dapat diambil kesimpulan sebagai berikut:

1. Penerapan Cooperative Learning tipe STAD pada mata pelajaran memahami sifat dasar sinyal audio berpengaruh terhadap hasil belajar siswa, dilihat dari hasil penelitian sesuai kepada KKM yaitu > 80. Hasil ujian mid siswa yang mencapai KKM berjumlah 6 orang siswa dari 12 orang siswa dengan rata-rata 68,33.Setelah di lakukan penelitian meningkat menjadi 8 orang siswa dari 12 orang siswa dengan rata-rata 81,17. Pada model 
pembelajaran lansung yaitu hasil ujian mid siswa yang mencapai KKM berjumlah 3 orang siswadari 13 orang siswa dengan dengan rata-rata 68,29 . Setelah di lakukan penelitian meningkat menjadi 4 orang siswa dari 13 orang siswa dengan rata-rata 74,85.

2. Melihat perbedaan tersebut dilakukan uji hipotesis dengan menggunakan uji t diperoleh adalah $\mathrm{t}$ hitung3,16 > t tabel1,713872 sehingga hipotesis alternatif diterima atau menolak hipotesis nihil (H0). Secara keseluruhan di peroleh bahwa pada kelas eksperimen jauh lebih baik dibandingkan dari pada kelas kontrol dengan persentase pengaruh 8,44\%.

\section{Daftar Pustaka}

[1] Sadirman. 2012. Interaksi dan Motivasi. Jakarta: PT Raja Gafindo Persada.

[2] Slavin, RobertE. 2005. Cooperative Learning teori, riset, dan praktik, penerjemah Narulita Yusron.Bandung: Nusa Media.

[3] A.MuriYusuf. 2010. Metodelogi Penelitian.Padang: Universitas Negeri Padang.

[4] Sugiyono. 2013. Metode penelitian pendidikan (Pendekatan kuantitatif, kualitatif, dan R\&D).Bandung: Alfabeta.

[5] Sudjana. 2011. Penilaian hasil proses belajar mengajar.Bandung.Remaja Rosdakarya Offset. 